\title{
ÁrNYÉKOKTATÁS: ALAPFOGALMAK, KUTATÁS, LEHETŐSÉGEK
}

\author{
GORDON GYŐRI JÁNOS
}

\author{
ELTE PPK Interkulturális Pszichológiai és Pedagógiai Intézet
}

A tanulmány az árnyékoktatás jelenségét az oktatási rendszerek legfontosabb vizsgatantárgyaira szűkítve definiálja, s e szük terület kutatástörténetének első két évtizedét mutatja be. A kutatás legfőbb témáinak, irányvonalainak, módszereinek és eredményeinek ismertetése után a szerző három olyan lehetőséget vet fel, amelyek az oktatáskutatásban az árnyékoktatáshoz kapcsolódóan is új lehetőségeket nyitnának meg, és amelyek a gyakorlatban hozzájárulhatnának az árnyékoktatás okozta egyenlőtlenségek mérsékléséhez: a szerző az oktatási viselkedéstudomány létrehozásának szükségességét, az oktatásitér-szakértők képzésének fontosságát, illetve az oktatási csekkek bevezetésének lehetőségét veti fel.

Kulcsszavak: árnyékoktatás-kutatás, oktatási viselkedéstudomány, oktatásitér-szakértő, oktatási csekk

In this article the author defines shadow education, as only the most important examination subjects' out-of-school, for-fee education activities belong here. After this he introduces some of the theoretical debates and important research tendencies, topics, methods and results of the first two decades of the field. Then he offers a new approach to reach a better understanding of shadow education and other educational phenomena, and two practical methods to reduce the negative effects of shadow education: he argues for starting educational behavior reseach, also for training so-called educational space specialist, and to introduce a well-balanced educational voucher system.

Keywords shadow education research, educational behavior science, educational space expert, educational voucher

Levelező szerző: Gordon Győri János, ELTE PPK Interkulturális Pszichológiai és Pedagógiai Intézet, 1075 Budapest, Kazinczy utca 23-27. E-mail: gyori.janos@ppk.elte.hu 


\section{Árnyékoktatás: miről is van szó?}

$\mathrm{A}$ z oktatás világa természetesen olyan gazdag társadalmi tevékenységrendszer, hogy annak valamennyi apróbb-nagyobb elemét számba venni, pontos, rendszeres teljességgel leírni, egyetlen egységes, ellentmondásmentes struktúrában látni és láttatni lehetetlen. Mégis, figyelemreméltó, ha egy olyan oktatási tevékenységtípusról hosszú ideig nem vesz tudomást az oktatáskutatás, amelynek igen sok változata, létmódja van, a világ minden táján elterjedt, és a társadalom számos rétege aktívan érintett benne. Márpedig éppen ez történt az árnyékoktatással: hosszú évtizedeken keresztül alig vagy még inkább egyáltalán nem vettek tudomást erről a jelenségről a kutatók és a szakemberek - sem itthon, sem nemzetközileg.

$\mathrm{A} z$ árnyékoktatás késlekedő azonosítása, konceptualizálása a nagy volumenű összehasonlító oktatási eredményességkutatásokkal - a TIMSS-szel és a PISA-val - párhuzamosan, részben azok hatására történt meg a 20. század legvégén, föleg annak köszönhetően, hogy a kelet-ázsiai tanulmányi eredmények kutatói igyekeztek feltárni a feltűnően jó eredmények minél több, addig akár ismeretlen oktatásügyi háttérösszetevőjét. Néhány megelőző, magas szakmai színvonaluk ellenére sem nagy hatással bíró korai közleményt követően (ld. Bray 2017; Gordon Györi 2020) a 20. század utolsó éveiben Stevenson és Baker (1992), illetve Bray (1999) egyaránt definiálták a tanulmányaikban, hogy mit is tekintenek az árnyékoktatás körébe tartozónak, hiszen egy olyan oktatási jelenséget kutattak, amelynek nemhogy konszenzuális meghatározása nem volt, hanem korábban csak igen kevesen ismerték fel az oktatáskutatásban, hogy ilyen jelenség egyáltalán létezik.

\section{Klasszifikáció}

$\mathrm{Az}$ árnyékoktatás fogalmi határvonalait, vagyis hogy mit tekintünk árnyékoktatásnak, a lehető legszükebben érdemes megvonni. Az iskola világán kívül zajló pedagógiai tevékenységterületek közül ez a szúk szegmens rendszerszintű kihívást jelent a formális nemzeti tömegoktatási rendszereknek, miközben azt kiegészítve, megtámogatva és egyben gazdagítva is a hétköznapi emberek sokasága és az oktatási szakemberek számára képes realitássá tenni a tanítás és tanulás gazdagon burjánzó, sok elemében szabályozatlan, nem formális társadalmi aktivitásának egy fontos szegmensét. Arra azonban, hogy milyen szempontokból jelent(het) az árnyékoktatás kihívást a formális oktatásnak - miközben azzal karöltve úgy járul hozzá a társadalmak oktatási gazdagodásához, hogy egyben látványossá teszi a formális oktatási rendszerek által hosszú időre beárnyékolt, de mindig is zajló tanulási és tanítási társadalmi aktivitások sokaságát -, csak a most következő klasszifikáció végén térek majd ki pontosabban.

Ahhoz, hogy az árnyékoktatás szűken értelmezett azonosítását meg lehessen tenni, érdemes néhány olyan kapcsolódó jelenségről lehasítani az árnyékoktatást, amelyeket a kutatók gyakran együtt kezelnek az árnyékoktatás szegmensével, és így elveszítik annak az esélyét, hogy pusztán magának az árnyékoktatásnak a jellemzőit azonosíthassák és annak valódi oktatásügyi konzekvenciáit levonhassák. A nemzetközi szakirodalom egy része a supplementary education (kiegészítő oktatás) terminológiát alkalmazza (Bray- 
Kwo-Jokić 2015), ami a tanításnak és tanulásnak szélesebb köre, mint az árnyékoktatás. Ugyanakkor a kiegészítő oktatás és az árnyékoktatás között olyan sok az átfedő jellemző, hogy némely közleményében még az árnyékoktatási kutatások vezető személye, Mark Bray is arra hajlik, hogy inkább kiegészítő oktatásról, semmint árnyékoktatásról beszéljen (ld. pl. Bray 2017). Amikor hazai oktatáskutatók azt a szélesebb jelenségkört kutatják, amelybe az árnyékoktatási szegmens is beletartozik, leginkább a tanórán kívüli tanulás (Imre 2020), a „különórák” vagy az extrakurrikuláris oktatás összefoglaló fogalmát alkalmazzák (Pásku-Münnich 2000). E tevékenységkör kutatása ugyan alkalmas lehet arra, hogy a tanulói időmérleg-kutatások (Suter 2016; Szénay 2003) során értékes és valós összefüggéseket tárjanak fel, és arra is alkalmas lehet, hogy ebben a fogalmi keretben mozogva fontos különbségeket mutathassunk ki a társadalmi közép- és felső osztályok gyerekeinek fejlesztési előnyeiről a leszakadó társadalmi rétegekbe tartozó gyerekekhez képest, de ez az ernyőfogalom lehetetlenné teszi éppen az árnyékoktatás speciális müködés- és hatásrendszerének a feltárását. Márpedig - mint arra utaltunk már - az oktatási tevékenységeknek ez a szegmense egészen más jelentőséggel bír, mint más részei.

A fogalmi rendszer eluzív mivoltát és a különféle fogalmak alatt tárgyalt oktatási jelenségek sokféleségét mutatja, hogy Kobakidze és Suter (2020) például több tucat megnevezésről és rendszerezésről beszélnek a témakörben. A továbbiakban egy olyan, alapvetően az oktatáspolitika szemléletmódjára építő klasszifikációs rendszert mutatunk be, amely eltér a „különórák” hazai szokásos rendszerezéseitől és némiképp a nemzetközi klasszifikációktól is, de amely - minden vitatható vonatkozásával együtt is - alkalmas arra, hogy elvezessen minket az árnyékoktatás szüken definiált fogalmáig.

\section{Co-kurrikuláris, a bivatalos állami tantervek kereteit kiegészitö iskolai foglalkozások}

Ezek nagyon változatos tartalmú és jellegü kiegészítő oktatási tevékenységek, amelyeknek közös jellemzője, hogy a) az iskola ajánlja fel; $b$ ) az iskola tanárai vagy meghívott oktatók tartják; c) ingyenesek vagy kis (gyakran szinte csak jelképes) összegbe kerülnek; d) önkéntes alapon múködnek; e) a formális oktatás keretei között müködnek ugyan, de sem szorosabban megfogalmazott jogszabály, sem a nemzeti alaptanterv vagy a kerettanterv nem szabályozza a tartalmi vagy formai jellemzőit; f) a tanulók nem kapnak osztályzatot; $g$ ) formai szempontokból nem befolyásolja a tanulók továbbhaladását az oktatásügyben. A magyar oktatásügyben legjellemzőbben az iskolai szakkörök, Japánban például a klubfoglalkozások (Gordon Győri 1998) tartoznak ide. A hazai szakirodalomban ezeket a foglalkozásokat jellemzően az iskolán belüli extrakurrikuláris foglalkozások csoportjába sorolják (Pásku-Münnich 2000).

\section{Nem formális oktatási tevékenységek}

\section{Iskolán kivüli extrakurrikuláris foglalkozások}

Ernyőfogalomként használva a hazai szakemberek (Pásku-Münnich 2000) gyakran minden iskolán kívüli oktatási formát idesorolnak, amikor iskolán kívüli extrakurrikuláris oktatásról beszélnek: a hegedüórát éppen úgy, mint az edzéseket a sportklubban, a nyári 
tehetséggondozó tábort, a magántanártól vett korrepetáló órát vagy a virágkötészeti tanfolyamot egy müvelődési házban. Ehelyett azonban érdemes egy tagoltabb rendszerezést alkalmazni az extrakurrikuláris címszó alatt:

\section{a) Hozzájáruló képzések}

Ingyenes vagy szignifikánsan a jellemzö piaci árak alatti képzések

Ezek ugyan alkalmasint hozzájárulnak az érintett tanulók formális oktatási rendszerekben történő elosztásához horizontálisan (azonos oktatási szinten intézmények és intézménytípusok között) és vertikálisan (az iskolafokozatok között), és ezért egyénileg igen fontosak lehetnek, de olyan kisszámú tanulót érintenek, hogy oktatásirendszer-szintű hatásuk nincs, illetve elhanyagolható. Ide tartozik - igaz, csak kevesek által kutatott jelenség (Kobakidze 2018) - ha például egy családtag gratis vagy jelképes összegekért korrepetál vagy tehetséggondozási értelemben fejleszt egy másik családtagot.

Alacsony költségbe kerülö vagy piaci árú, de nem az iskolai elméleti tantárgyakat lefedö képzés

Ezek olyan ingyenes, jelképes összegbe kerülő vagy akár piaci áron felajánlott foglalkozások, amelyek a formális oktatási intézményben tanuló diákok túlnyomó többségének az iskoláiban nem oktatott tudásterületeket fednek le. Ilyen lehet például egy cimbalomóra, sportolás egy egyesületben, filmesztétika tanfolyam egy müvelődési házban, az EU által felajánlott multikulturális kommunikációt fejlesztő nyári tábor, egy egészségügyi tanfolyam a cserkészet körében és hasonlók. Ezek a legtöbb tanuló számára gazdagító, nem pedig az oktatási rendszerekben való elosztásukat és továbbjutásukat elősegítő képzések. Egyénileg ezek a képzések is igen fontosak és akár elméleti jellegűek is lehetnek (például egy héber nyelvtanfolyamra járó középiskolás tanuló esetében, aki hebraisztika szakra szeretne jelentkezni az egyetemen), de ezek a képzések is olyan kisszámú tanulót érintenek, hogy oktatásirendszer-szintű hatásuk nincs, illetve elhanyagolható.

b) Árnyékoktatás - az elméleti iskolai tudásterületeket lefedö, piaci árú magánoktatási tevékenységek

Árnyékoktatás: szélesebben értve

Ezek a képzések szorosan követik a formális oktatás tartalmi igényeit, piaci szolgáltatások, az adott tanulók számára lényeges hatással bírhatnak az oktatási rendszerben való elosztásra, de oktatásirendszer-szinten ezeknek a hatása is elhanyagolható. Idetartozik például, ha egy tanuló fizika korrepetálásra jár egy erre szakosodott délutáni oktatási intézménybe, vagy biológiából, kémiából felkészíti őt egy magántanár a felvételire, mert a tanulói szelekció folyamatait ezek a tantárgyak csak nagyon kevés tanuló esetében befolyásolják lényegesen.

\section{Árnyékoktatás: szükebben értve}

Ez a szük szegmens azonban csak azt a három - némely esetben még további egy-két tantárgyat tartalmazza, amelyek Mark Bray (1999) megközelítésében is az árnyékoktatás 
lényegét adják. Ide ugyanis jellemzően csak azokat a piaci áron oktatott tantárgyakat lehet besorolni, amelyek a tanulók sokaságának a nemzeti oktatásügyek rendszerében, illetve adott esetben a globális oktatás világrendszerében történő horizontális és vertikális (képzéstípusok és oktatási fokozatok, illetve konkrét oktatási intézmények szerinti) elosztását döntően befolyásolják is. Ezek: a matematika, idegen nyelv (a világ legtöbb pontján az angol nyelv), illetve a( $z$ anyanyelvi) szövegértés, szövegalkotás.

Bray klasszikusnak tekinthető 1999-es leírása (Bray 1999; Zhang-Bray 2020) szerint árnyékoktatásként az az oktatási tevékenység azonosítható, amely

- kiegészitő, vagyis olyan tantárgyat fed le, amelyet az iskolákban szokásos módon oktatnak

- piaci áron zajló privát oktatási tevékenység

- az oktatási rendszer átfogó részében elméleti, vizsgatantárgyként is alkalmazható tantárgyat (angolban: examinable academic subject) fed le.

Mindezen jellemzőik mentén a co-kurrikuláris, illetőleg az extrakurrikuláris, de nem árnyékoktatási nem formális oktatási tevékenységek azért különíthetők és különítendők is el mindattól, ami az árnyékoktatás körébe sorolható, mert csak ez az utóbbi oktatási tevékenységcsoport alkalmas arra, hogy az oktatási rendszer legfőbb szelekciós mechanizmusait érintő hatásán keresztül lényeges befolyással bírjon a formális tömegoktatási rendszerekre, és így a társadalmi egyenlőségi, méltányossági és stratifikációs folyamatokra (Dawson 2010; Yung-Bray 2017) is - akár a társadalmi stratifikációt egyenlőségelvű mivoltában segítő, akár azt negatívan torzító vonatkozásaiban.

$\mathrm{Az}$ oktatásipar (EdTech) mellett vagy annak részeként értve jelenleg kizárólag az árnyékoktatási szegmens az, amely a legmagasabb gazdasági szintekig képes lehetett és képes is volt indusztrializálódni, a tömegoktatási rendszerek megjelenése óta az első olyan oktatási szegmensként működni, amely képes lett a formális nemzeti oktatási rendszerek müködését, az iskolai tanárok értékrendjét és viselkedésmódját lényegesen befolyásolni (Qin et al. 201911), mélyreható igazságérzeti és érzelmi hatásokat kiváltani a társadalom széles rétegeiben, de különösen a tanulók, szülők, tanárok és oktatáspolitikusok körében.

Mindezt úgy érte el az árnyékoktatás, hogy - szemben a nemzeti formális oktatási rendszerekkel, illetve az ezeket létrehozó személyekkel - az árnyékoktatásnak ismereteink szerint nincs világosan beazonosítható, koherens filozófiája, nem épül antropológiai nézetrendszerekre, nincs etikailag is megalapozott - mondjuk például Comenius elméletére emlékezetető - morális-teleologikus víziója az egyéni és társadalmi jóról és az ezek integrált eléréséhez vezető, kívánatos utakról az oktatás terén. Ha valami, önmagukban e jellemzők is indokolttá teszik az árnyékoktatással való behatóbb foglalkozást.

\section{$\mathrm{A} z$ árnyékoktatás kutatásának első két évtizede}

\section{Az első évtized: a jelenség azonositása, definiálása, alapvető jellemzöinek feltérképezése}

$\mathrm{A} z$ árnyékoktatás jelenségének kutatása a privát oktatás kutatási irányvonalának megerősödésével párhuzamosan (Tooley 1999), nagyjából az 1990-es években kezdődött

1 E tanulmány lefordításáért szeretném köszönetemet kifejezni Pu Yu doktori hallgatómnak. 
meg. Néhány, lényegében visszhangtalan, noha szakmailag fontos közleményt (George 1992; Hamechandra 1982; Hussein 1987; Inkei-Koncz-Pöcze 1988; Marimuthu et al. 1991; Roblen 1980) követően Stevenson és Baker 1992-es cikkével (Stevenson-Baker 1992), illetve Mark Bray 1999-es könyvével (Bray 1999) indult fejlődésnek a téma kutatása. Ezek, illetve az ezt követő első évtized a jelenség pontosabb azonosításával és így definiálásával, Bakerék esetében a japán nemzeti, Bray esetében a globális terep feltérképezésével telt el.

Az első kutatási évtized további szerzői igyekeztek a jelenséget, lokálisan és általánosan azonosítani és definiálni azt, valamint arra törekedtek, hogy feltárják kialakulásának, elterjedésének történeti folyamatait, az egyes társadalmakban való jelenlétének szélességét, elterjedtségét, leírják különféle változatait, típusait, ezek fő funkcióit, egy sor demográfiai jellemzőjét, mint például az árnyékoktatás életkor/iskolafokozat szerinti jellemzőit, az árnyékoktatást igénybe vevő családok szociodemografikus jellemzőit, a fiúk és lányok közötti különbségeket az árnyékoktatás igénybevételével kapcsolatban, a települési jellemzőket. A kutatók igyekeztek feltárni az árnyékoktatás alapvető összefüggéseit a formális oktatási rendszerrel és azon belül különösképpen az oktatás horizontális és vertikális szelekciós elemeivel való összefüggéseit, kölcsönhatásait, összefüggéseit a nagyvolumenű nemzetközi összehasonlító oktatási eredményességkutatásokkal (eleinte még csak a TIMSS-szel, 2000-et követően a PISAval is), illetve alkalmasint a hasonló nemzeti kutatásokkal, az árnyékoktatás gazdasági és pénzügyi vonatkozásait nemzeti, vállalkozási, családi léptékekben, az árnyékoktatási rendszerek müködésének kulturális tényezőit, mint például a tanulás értéke a társadalomban és a családok-egyének körében, az árnyékoktatásra adott politikai, oktatáspolitikai és általános társadalmi válaszokat (Zhang-Bray 2020).

\section{A második évtized: bövités, mélyités, finomitás}

Zhang és Bray (2020) összegzése szerint a kutatás második érvtizede az első évtized globális képe után igyekezett feltárni az árnyékoktatás társadalmi-oktatási ökoszisztémáját annak átfogó és finomabban részletezett, közelképibb metszeteiben egyaránt, olyanféle témákat állítva a középpontba, mint például az árnyékoktatás összefüggését az iskolázás jelenségével, a szülői magatartással és a társadalmi-gazdasági fejlődésfolyamatokkal, az árnyékoktatásra vonatkozó oktatáspolicyk elméletét és gyakorlatát, a jelenség mélyebb szociológiai és gazdasági összefüggéseit, közöttük, a társadalmi csoportok hatalmi viszonyait az árnyékoktatás összefüggésrendszerében, illetve a neoliberális és neoinstitucionalista ideológiák összefüggésit az árnyékoktatással (Zhang-Bray 2020: 5).

Ugyanebben az évtizedben nagymértékben bővült az árnyékoktatás kutatásmódszertana és kutatási eszköztára is (Bray-Kwo-Jokić 2015). A korábbi, pozitivista jellegű kutatási megközelítés kvantitatív irányvonala mellé ekkoriban csatlakoztak be a kvalitatív és a kevert kutatási megközelítések is, amelyek jelentősen finomították az árnyékoktatás közelképi metszeteit a korábbiakhoz képest.

Mindezzel összefüggésben a kutatás tematikus bővülése is jelentős volt ebben az évtizedben. Egyre több kutatás irányult immár az árnyékoktatási kurrikulumokra (KimJung 2019b), az árnyékoktatás szerepére a speciális képzési igényü tanulók esetében, például a tehetséggondozásban (Kim-Jung 2019a), az iskolai tanárok és az árnyékoktatási 
tutorok identitás- és szakmaifejlődés-kérdéseire (Kobakidze 2018), az árnyékoktatás hatására a formális oktatásban tevékenykedő tanárok célrendszerére és módszertanára, a szülők és a tanulók elvárásrendszereire, az árnyékoktatás és a formális iskolák kapcsolatrendszerére (Entrich 2018), az oktatási innováció és az árnyékoktatás viszonyrendszereire, az addigi oktatáspolitikai reakciók hatásrendszerére, az árnyékoktatási szakmai csoportok érdekvédelmi stratégiáira és minőségvédelmi technikáira, a tanulók tanulási technikáira az árnyékoktatásban, a tanulási hibridizációra és más témákra. Valamint természetesen egyre többször tudtak a kutatók, szakemberek arra vonatkozóan is figyelmet fordítani, hogy az igazság, egyenlőség és méltányosság kérdéseit milyen módokon és hogyan befolyásolja az árnyékoktatás a társadalomban és az oktatásügyben.

Jelen tanulmányban természetesen meg sem kísérelhetjük, hogy az első két évtized kutatási eredményeit akár csak felsoroljuk, nemhogy részletesebben bemutassuk azokat. A továbbiakban csak jelzésszerüen van mód utalni néhány kutatási eredményre, és azokra is csak azzal a megszorítással, hogy bármelyik eredményre vonatkozóan fellelhetők akár teljesen ellentétes eredmények és értelmezések is. A kutatási eredmények tehát jócskán ellentmondásosak. Annyit azonban nagy biztonsággal ki lehet jelenteni, hogy Baker és Bray korai közleményei és a napjaink között eltelt két évtized során az árnyékoktatás az oktatáskutatás és oktatástudomány egyik legizgalmasabb és legdinamikusabban változó, lendületesen fejlődő területe lett.

\section{Az árnyékoktatás kutatásának néhány eredménye}

\section{Általános elterjedtség}

$\mathrm{A} z$ árnyékoktatás nemzetközi kutatásának legfontosabb eredménye az, hogy az adatokból világossá vált: az árnyékoktatás globális oktatásügyi jelenség, nem pedig csupán a konfuciánus, gazdaságilag és oktatásügyben fejlett és hatékony kelet- és délkelet-ázsiai országok sajátossága (Gordon Györi 1998; Manzon-Areepattamannil 2014; StevensonBaker 1992), ahogy azt az első közlemények szerzői feltételezték. Érdemes megjegyezni, hogy bár az árnyékoktatást igénybe vevők korosztályos aránya a skandináv országokban alacsonyabb, mint szinte bárhol máshol a világon, azért az észak-európai országokban is jelen van. Sőt azt is tudjuk, hogy még ha kevéssé elterjedt is ebben a régióban, azért a felsőoktatásba való bejutás egyenlőségelvű esélyeit ezekben az országokban is figyelemreméltó mértékben képes befolyásolni (Kosunen 2018).

\section{Településtípusok szerinti elterjedtség}

$\mathrm{A} z$ árnyékoktatási kutatásokban, illetve a kutatási eredmények értelmezésében fontosak a területi szempontok. Globálisan, országonként, régiónként és más településtipológiai jellemzők mentén vizsgálva is jelentős eltérések lehetnek az árnyékoktatás elterjedtsége, jellege, szociális különbségeket tükröző és más vonásai között. Jelenleg nem ismerünk olyan országot, amelyben a metropoliszok, nagyvárosok, városok kevesebb árnyékoktatási lehetőséget biztosítanának, mint a kisebb települések. Igaz, az online oktatási formák miatt változóban van a területi egyenlőtlenség. De ez nem változtat egyrészt azon, hogy a tanár és a tanuló személyes fejlesztésén alapuló kiegészítő magánoktatási szolgáltatásokhoz így is a városi-nagyvárosi tanulók jutnak könnyebben hozzá, másrészt nem 
változtat azokon a társadalmi különbségeken, amelyek azt befolyásolják nagymértékben, hogy egy-egy tanuló mennyire jut vagy nem jut hozzá a tanulását támogató árnyékoktatási lehetőségekhez.

\section{Az árnyékoktatás kibontakozását segitő néhány strukturális, kulturális és csoportpszichológiai tényezö}

Ezek nagymértékben változnak országonként, oktatási rendszerenként. A strukturális elemek közül általában a vizsgarendszer meglétét szokták kiemelni (magyar adatokkal is: Długosz 2017). Vagyis miközben a vizsgarendszerek az oktatási egyenlőségelvet hivatottak szolgálni, paradox módon éppen ez az egyik faktora az oktatási egyenlőtlenséget növelni is tudó árnyékoktatási rendszerek létrejöttének, müködésének és megerősödésének. Miközben azonban az oktatás vertikális rendszerelemei, vagyis az iskolafokozatok közötti átmenet és az árnyékoktatási részvétel összefüggéseinek vizsgálata viszonylag gyakoribb volt az elmúlt két évtizedben, arra kevesebb figyelem irányult, hogy milyen összefüggés van az árnyékoktatás és a valamely iskolafokozaton megtalálható iskolatípusok választása között. Az e téren fellelhető adatok arra mutatnak, hogy a társadalmak közép- és afölötti rétegei számára az árnyékoktatás a minél magasabb presztízzsel rendelkező iskolatípusok és intézmények választásához hozzásegítő oktatási lehetőségként jelenik meg.

Mindamellett az árnyékoktatás jelenléte és piaci elterjedtsége, valamint e szegmens olykor igencsak - agresszív piacpolitikája többféle racionális vagy csupán racionálisnak vélt döntéshelyzetbe sodorja a szülőket és a gyerekeket. Amikor ugyanis az árnyékoktatás egy társadalomban vagy annak valamely szegmensében elér egy arra a közösségre jellemző kritikus tömeget, akkor a tanulók és a szülők elkezdik úgy érezni, hogy a gyerekek lemaradnak az oktatási versenyben, ha nem vesznek részt annak a formális iskolai rendszeren kívüli, árnyékoktatási változataiban is (Entrich 2018; Fülöp-Gordon Györi 2020).

Ugyanakkor érdemes felfigyelni arra, hogy némelyik társadalomban az egyes társadalmi csoportok nem lényegesen különülnek el egymástól a tekintetben, hogy az oda tartozó gyermekek igénybe veszik-e az árnyékoktatási szolgáltatásokat vagy sem, sokkal inkább abban, hogy milyen intenzíven élnek ezzel a lehetőséggel, mennyire hatékonynak gondolt formáival élnek, milyen családi összköltségeket fordítanak erre az oktatási szegmensre. Feltehető, hogy abban, hogy a kelet-ázsiai országokban az árnyékoktatás igénybevétele valamennyi társadalmi csoportban és szegmensben sokkal szélesebb, mint például az észak-európai országokban, szerepet játszanak a kulturális tradíciók, a kulturális érték-, norma-, és hiedelemrendszerek is.

\section{Az igénybe vevök jellemzői}

Életkori jellemzők

$\mathrm{A} z$ árnyékoktatás igénybevételének a tanulók életkorára vonatkozó jellemzői nagy változatosságot mutatnak társadalmanként, oktatási rendszerenként és kultúránként. Noha az óvodáskori árnyékoktatás jelensége is ismert (Entrich 2018), az árnyékoktatás igénybevétele inkább az iskoláskorhoz köthető - és azon belül legjellemzőbben a szelek- 
ciós periódusok (felvételi vizsgák stb.) időpontjaihoz köthetően -, bár egyáltalán nem atipikus az egyetem alatti igénybevétele sem (Ceglédi és Szabó 2014).

\section{Nemek szerinti eloszlás}

A kutatások szerint több fiú jár árnyékoktatásba, mint lány (Bray 1999), bár egyes országokban ez kiegyenlített vagy éppen fordított arányú (Kassotakis-Verdis 2018). Általában, bár nem kizárólagos tendenciaként az tapasztalható, hogy a fiúk árnyékoktatására a családok többet költenek, mint a lányokéra. Ennek egyrészt az lehet az oka, hogy a fiúk közül többen szorulnak remediáló (korrepetáló) árnyékoktatási támogatásra, mint a lányok, másrészt az, hogy a családok hosszabb távú célok érdekében szívesebben költenek a fiúkra, mint a lányokra, akik később esetleg nagyobb valószínüséggel nem lesznek kenyérkeresők. Mindazonáltal e klasszikusnak tekinthető mintázat erősen függ az adott oktatási rendszer bizonyos összetevőitől, az adott oktatási környezet kultúrájától, hagyományrendszerétől, e környezet gazdasági jellemzőitől. Így aztán arra is találhatók példák, hogy inkább a lányok járnak árnyékoktatásba, kevésbé a fiúk (lásd pl. Polónyi 2020; Qin et al. 2019).

\section{Társadalmi csoportok szerinti eloszlás}

Noha a társadalomtudományi kutatások terén ma már sokan elvetik a klasszikus osztályelméleteket (Barbalet 1986), az árnyékoktatás-kutatók a kezdetek óta a felső osztályok, a középosztályok és a leszakadó társadalmi osztályok hármas osztatú rendszerében szokták elhelyezni az árnyékoktatás igénybevételének társadalmi csoportok szerinti jellemzőit. Ezek a felosztások szinte mindig azt mutatják, hogy a gazdagító árnyékoktatás nagy fogyasztója a saját társadalmi előnyeinek fenntartása és megerősítése érdekében a középosztály, míg a leszakadó csoportok vagy szignifikánsan kevésbé akarják és/vagy tudják igénybe venni az árnyékoktatási piac lehetőségeit, vagy inkább csak korrepetáló céllal, vagy alkalmasint a középosztályba jutás reményében a hosszabb távú, bizonytalan családi erőfeszítések lehetőségeként élni vele (Andor 1999).

$\mathrm{A} z$ árnyékoktatás igénybevételének osztályszempontú, nem ritkán Bourdieu tőkeelméleteire építő magyarázatát (Borudieu 2003; Entrich 2018; Tsiplakides 2018) olykor a kulturális elméletekkel igyekeznek kritizálni vagy cáfolni, jelezve, hogy egyes társadalmakban a kulturális forgatókönyvek gyakran felülírják a szülők oktatási döntéseinek a társadalmi osztályokba tartozásból következő logikáját. E kulturális logikák az oktatás minden lehetőségének minél teljesebb igénybevételére akár a reális anyagi lehetőségeiken is túlmutató áldozatok meghozatalára serkentik a szülőket (Lee 2006). Mindamellett érdemes felfigyelni arra, hogy e megközelítések elhanyagolják azt a hatást, miszerint egyegy társadalmi csoporton belül az árnyékoktatás igénybevétele a plusz tanulási erőfeszítésnek köszönhetően végül is mégis csak meritokratikusan szerzett előnyökhöz és így egyfajta igazságos szelekcióhoz vezethet az oktatásban - az adott csoport kontextusában.

\section{$A z$ árnyékoktatás igénybevételének strukturális okai}

Mint szó volt róla, a „magántanítás” történetileg egyáltalán nem új jelenség - történetileg valójában sokkal régebbi, mint a formális oktatás. Mindamellett a tömegessé válásának, 
vagyis annak, hogy a társadalom különféle csoportjai a világ számos pontján nagy arányban veszik igénybe ezt a képzési szegmenst, jelentős strukturális okai vannak. Ezek közül elsődleges szerepet játszik az oktatás tömegessé válása a nemzeti tömegoktatási rendszerek kialakulásával, ami ugyanakkor szükségszerűen magával hozta a tömegoktatás által soha nem igazán megvalósítható, egyénre szabottabb tanítási formák tömeges igényét is. Az árnyékoktatás tömegességét, megerősödését kiváltó fontos strukturális elem a tömegoktatási rendszerekben elterjedt szelekciós mechanizmusok rendszere, különösen a vizsgarendszerek megjelenése (Marimutbu et al. 1991). Ezzel összefüggésben fontos az, hogy a felsőoktatás is tömegoktatássá vált a világ számos országában, és az ide - illetve ezen belül a lehető legjobb képző intézményekbe - való bejutás biztosítása a családok/ gyerekek nagy tömegei számára fontos cél lett. Az árnyékoktatás tömegessé válását és indusztrializálódását befolyásoló tényezők között található az oktatási eredményességi rangsorok széles körű elterjedése az oktatás különböző léptékeiben, az iskolákon belüli és iskolák közötti mérésektől a nagy nemzeti és nemzetközi mérésekig és rangsorokig bezárólag (kompetenciamérés [Szemerszki 2020], TIMSS, PISA, egyetemi rangsorok és más összehasonlító mérések). Ezen a szálon haladva akár az is joggal mondható, hogy az árnyékoktatás robbanásszerű elterjedésének a komparatív pedagógiai mérések, kutatások - és azon belül éppenséggel akár maguk a komparatív árnyékoktatási kutatások - maguk is kiváltó elemei voltak.

De valószínűleg mindezeknél fontosabb, és persze másféle strukturális tényező az, hogy az elmúlt évszázadok során a felfelé irányuló társadalmi mobilitás döntő - de legalábbis egyik fontos - tényezőjévé vált az oktatásban elért eredményesség, amelyben az emberek nagy tömegei még akkor is joggal hihetnek, ha egyébként a hétköznapi élettapasztalataik ezzel sok esetben nem vágnak egybe. Mindamellett e hitnek a gyökerei az ázsiai társadalmakban jóval a formális oktatási rendszerek kialakulása előttre nyúlnak vissza (ld. a kínai vagy koreai versenyvizsgarendszereket; pl. Kalmár 1995).

\section{Az árnyékoktatás jellemzö formái, technikai eszközrendszere és módszertani eszköztára}

Az árnyékoktatás legjellemzőbb - mondhatnánk: klasszikus - formája az egy az egyben, szemtől szemben történő individuális oktatás. De van, hogy két vagy több tanulót tanít egy tanár egyszerre. Ugyanígy előfordul osztálynyi tanuló egyszerre történő oktatása, vagy még nagyobb, akár többszáz fős csoportban történő oktatás. Az egyszerre oktatott tanulók létszámának bővülése azért is történhetett meg, mert az árnyékoktatás területén az 1980-as évekre nagy, ipari méretü cégek jelentek meg, amelyek az oktatás lehetőségeit fizikailag és technológiai szempontokból is ki tudták terjeszteni, például többszáz fős nagyelőadók használatával és hasonló módokon. Ezzel párhuzamosan a tanulói létszámok határait az 1980-as években a szatellit-, azóta pedig a digitális technika lényegében megszüntette, és az egyéni online oktatástól kezdve a nem számszerüen meghatározható tanulói létszámhatárig flexibilissé tette. Nem lényegtelen fejlemény, hogy ezzel együtt az árnyékoktatás igénybevételének idői határai is feloldódtak mindazon esetekben, ha nem valós idejű (szinkrón) tanítás történik. Hiszen a fizetett internetes tanítási szolgáltatásokat bármely tanuló bármikor igénybe veheti. Mindez azonban már az oktatástechnológia, az oktatásipar határterületein elhelyezkedő lehetőség 
- és itt a két terület, az árnyékoktatás és az oktatásipar területe nehezen elválasztható módon összeér.

Ugyanakkor figyelmet érdemel, hogy az árnyékoktatási kutatások eddigi két évtizedében a tanítási módszerekről, az árnyékoktatási metodologiá(k)ról alig született alaposabb tudományos elemzés (a kevés kivétel között lásd Kim-Jong 2019a).

\section{Az árnyékoktatás szolgáltatói oldala, különös tekintettel a tanárokra}

Mint szó volt már róla, a szolgáltatást végzők spektruma a (gyakran nem bejelentett és így nem is adózó) egyéni magántanári szolgáltatóktól (Bíró 2020; Dierkes 2010) kezdve nagyipari, akár kontinenseken is átnyúló nemzetközi franchise oktatócégekig terjed. De akármilyen szerveződési szintről van is szó, az árnyékoktatás-iparnak ugyanúgy a tanárok a legfőbb aktorai, mint a formális tömegoktatásnak. Ezen belül azonban sokkal nagyobb és sokkal vegyesebb tanári összetétellel találkozunk. Az árnyékoktatási tanárok között ugyanúgy találhatunk képzett, mint képzetlen oktatókat (Gordon Győri 1998; Kobakidze-Suter 2020), praktizáló tanárokat (Mayer 2003), pályaelhagyókat vagy nyugdíjasokat, tanárképzésben részt vevő vagy más felsőoktatási hallgatókat (Ceglédi-Szabó 2014), vagy akár középiskolás diákokat (Bankó 2009; Ho Nga Hon 2010).

Éppen az árnyékoktatás piaci jellege miatt az árnyékoktatásban kialakult a tanárok egy új csoportja: az úgynevezett sztártanárok. A sztártanárság alapja természetesen ugyanúgy a népszerűség, mint a formális oktatásban a kedvelt tanárok esetében, de a sztártanárok jövedelme minden létező oktatási hagyománytól különböző nagyságrendű (nemritkán éves szinten több millió dollár [Kim-Jung 2019a]), a tanítványaik köre pedig ennek megfelelően ugyancsak messzemenően szélesebb, mint bármely közoktatási tanáré. Egy sztártanár ugyanúgy felépített és marketingelt/menedzselt termék, mint például egy popsztár, és a produktumain - vagyis a tanítási óráikon - olykor ugyanúgy nagylétszámú háttércsapatok dolgoznak, mint a popsztárok produktumain.

\section{Az árnyékoktatás és a formális tömegoktatás kölcsönhatásai}

$\mathrm{Az}$ árnyékoktatás és a formális oktatás kölcsönhatásai nagyon széles körűek, ennek megfelelöen széleskörủen kutatottak is. Ezen a téren negatív és pozitív kölcsönhatásokról ugyanúgy beszélhetünk, mint nehezen megítélhető kölcsönhatásokról. Egyrészt az árnyékoktatást igénybe vevő tanulók általános, de nem kizárólagos tapasztalata szerint az árnyékoktatási tanárok jobban el tudják magyarázni a tananyagot és ezzel elősegíteni a tanuló iskolai munkáját is, mint a formális oktatásban dolgozó tanárok (Kim-Jung 2019a; Qin et al. 2019). Viszont azokban az országokban, ahol nagyon alacsony a tanárok jövedelme, nem ritka, hogy a saját osztálytermi tanítványaikat oktatják a tanárok délutánonként árnyékoktatási tanárként. Annak érdekében, hogy ez a piaci lehetőségük működjön és így megfelelő jövedelemre tegyenek szert, egyéb etikátlan technikák mellett (Ghosh-Bray 2020) a tanárok akár vissza is tartják a tananyag egy részét a közoktatási óráikon. Van ország, ahol a diákok hamis orvosi papírral eltávoznak napközben az oktatási intézményükből, hogy egy árnyékoktatási intézményben töltsék tanulással a délelöttjüket. Mindez súlyos etikai kérdéseket vet fel a fóáramú oktatásban, de egyébként is.

Ugyanakkor az árnyékoktatási szolgáltatások és a fóáramú oktatás nem feltétlenül csak versenyeznek egymással, hanem közös érdekek mentén akár együtt is tudnak mü- 
ködni. Ennek egyik nem ritka formája például az, hogy árnyékoktatási intézmények pályaválasztási szolgáltatást nyújtanak a fóáramú oktatási intézményeknek is (természetesen saját piaci előnyszerzés érdekében is).

\section{Az árnyékoktatás eredményessége}

Ez a kérdés már az árnyékoktatással foglalkozó legelső kutatási közleményekben megjelent (Marimutbu et al. 1991; Stevenson-Baker 1992), és azóta is az egész kutatási irány egyik alapvető témája. Talán zavarba ejtő módon mégis azt kell mondani, hogy valójában erre a kérdésre nem tudunk pontos választ adni - és ennek többféle oka is van.

Egyrészt nem teljesen tisztázott kutatásilag, hogy milyen adatokat keresnek is szakemberek, amikor az eredményesség adatait keresik: A tanulók évközi osztályzatait? Felvételi eredményeik mutatóit? Versenyeredményeket? Attitűdváltást? Rövid vagy hosszú távú különbségeket?

Másrészt mint az oktatáskutatás egyéb területein is - főleg ha hosszú távú eredményváltozásokat nézünk - az árnyékoktatás lehasítása minden más befolyásoló tényezőtől lényegében lehetetlen, bármilyen finom számítási és elemzési módszerekkel dolgozzanak a kutatók. Valamint sokkal könnyebb együttjárásokat, mint valódi ok-okozati tényezőrendszereket feltárni ezen a téren (is).

Végül: mint szó volt róla, az árnyékoktatás maga is olyan sokféle fajta képzés- és tanulói-tanári aktivitástípusra oszlik, hogy valójában nem lehet megmondani, hogy az árnyékoktatás mint olyan mennyire hatékony, legfeljebb csak annyit lehetne mondani, hogy a sokféle árnyékoktatás ilyen vagy olyan változata ilyen vagy olyan körülmények között milyen hatást látszik kifejteni.

Mégis az mondható, hogy a kutatók tendenciaszerüen inkább azt találják, hogy valamennyi pozitív hatása van az árnyékoktatásnak. De lehet, hogy a téma megközelítésének nem is ez az igazán adekvát kutatói iránya, hanem inkább az, hogy hisznek-e benne a szülők és a tanulók, vagyis a fogyasztók, vagy sem. Végül is az magyarázza az árnyékoktatás sikerességét, hogy különféle okokból, de a fogyasztók többsége hisz e szolgáltatás hatékonyságában (még akkor is, ha természetesen mindig vannak olyan fogyasztók e téren is, akik végül is csalódnak abban, amit a várt szolgáltatástól kaptak [Kim-Jung 2019a]).

\section{$A z$ árnyékoktatás szabályozása}

$\mathrm{A} z$ árnyékoktatás-kutatás egyik fő területe az árnyékoktatás szabályozásának kérdése. Ennek egyik fontos, de korántsem kizárólagos oka az, hogy a terület vezető szakembere, Mark Bray az összehasonlító pedagógiatudomány müvelésén túl az oktatáspolitika nemzetközi vezető szakembereinek egyike. A szabályozás kérdése nagyon összetett és bonyolult kérdés, amelyben szorosan értett oktatáspolitikai tényezők éppúgy jelen vannak, mint gazdasági, jogi, társadalompszichológiai, kulturális és még számos más tényező. Mark Bray és Kwo (2014) a szabályozás számos formáját és lehetőségét tárták fel, illetve fogalmazták meg; Zhang (2019) pedig a mai kínai gyakorlatot mutatja be a szabályozás terén. E technikák bemutatása jelen tanulmány terjedelmi keretei között nem lehetséges, ezért csak két érdekes vonatkozást említünk most. 
Az egyik említésre méltó vonatkozás az, hogy az árnyékoktatást formális jogi eszközökkel lehetetlen betiltani, noha többször megkísérelték már. Dél-Koreában kétszer is nagyon szigorú törvények segítségével próbálták megszüntetni, de ez az igyekezet mindkétszer megbukott (Kim-Jung 2019a). Valószínúleg ugyanúgy nem lehet betiltani, mint ahogy az emberek közötti gazdálkodást sem, amely a formális gazdaságokat szabályozó korlátok mellett ugyancsak nagy szélességben működik a társadalmakban, és még egészen szélsőséges társadalmi körülmények között sem szünik meg, sőt. Egy másik fontos ismeret erről a kutatási területről az, hogy az állami jogi szabályozáson kívül létezik a terület szabályozásának egy másik fajtája is: a szakma céhszerü önszabályozása (BrayKwo 2014). Ennek célja egyébként elsősorban a piaci szolgáltatás színvonalának megtartása és emelése, az ezt veszélyeztető vagy elérni nem tudó cégek és személyek kiszürése.

Az árnyékoktatások kutatásának még számos olyan területe van, amelyre vizsgálatok, tanulmányok tucatjai vonatkoznak évente, de amelyekre a terjedelmi lehetőségek miatt e tanulmányban nincs mód kitérni. Ilyen például az árnyékoktatás oktatásgazdaságtana (Polónyi 2020).

\section{Következtetések}

$\mathrm{A} z$ árnyékoktatás megítélése nagyon szélsőséges. Igazi „szépség és szörnyeteg” jelensége ez az oktatás világának. Míg egyesek élősködőnek és az oktatásügyek betegségének tekintik (Kassotakis-Verdis 2018), addig mások a társadalom oktatási autonómiájának megnyilvánulását látják benne az állami oktatásügyek ellenében (Ural 2012). Noha mindkét szélsőség kapcsán jelentős szakmai és társadalmi érvek és ellenérvek hozhatók fel, valószínüleg érdemesebb úgy kezelni ezt a jelenséget, mint aminek a hatása igen sokféle lehet, már csak annak a társadalmi és oktatási térnek a sokfélesége miatt is, amelyben az árnyékoktatási rendszerelemek maguk is müködnek a világ legkülönfélébb pontjain. Az árnyékoktatás-kutatás egyértelmúen feltárta, hogy a 20-21. században az oktatás globális folyamatai a formális oktatási rendszereket körülvevő társadalmi aktivitás soha nem látott bővülését hozták magukkal. Érdemes felfigyelni arra, hogy az oktatási tér ilyen szintü, bővülő tagolódása nagyrészt tervezetlen, spontán és ellentmondásokkal teli folyamatok eredményeként zajlott le, hasonlóan ellentmondásokkal teli lehetőségeket hozva létre.

Mindazonáltal e folyamatok tervezetlensége nem jelenti azt, hogy az oktatási szakembereknek, oktatáspolitikusoknak, kutatóknak vagy más résztvevőknek a jelenség mélyebb megértése mellett ne lehetne aktív tevékenységet is folytatniuk az árnyékoktatás müködésének és hatásrendszerének befolyásolásában. Mark Bray írásaiban bőven találni oktatáspolitikai példákat és javaslatokat az árnyékoktatás szabályozására (Bray-Kwo 2014). De további lehetőségek is léteznek. Ilyen például az élethossziglani tanulás támogatási rendszereinek (lifelong guidance; LLG; lásd pl. Borbély-Pecze-Kovács-Répáczki 2012) célzott kiterjesztése oktatásitér-szakértők (ennek egy változatát lásd Silber 1972; idézi Setényi 2020) bevonása segítségével a hátrányos helyzetű csoportokra annak érdekében, hogy az egyre komplexebbé váló oktatási ökoszisztémában az e csoportokba tartozó személyek is hatékonyan ismerhessék ki magukat és hatékonyan dönthessenek az idevonatkozó kérdésekben. Ennek anyagi keretét a felhasználók számára a Magyarországon ritkán szóba hozott, de a világ számos táján alkalmazott, és az egyéni tanulási utak kialakításában az árnyékoktatás igénybevétele vonatkozásában is megfontolandó 
lehetőségeket magában hordozó oktatási csekkekkel (Bray 2017; Doherty-Dooley 2018; Kobayashi 2018; Murnane et al. 2017) is meg lehetne teremteni. Mindennek szakmaitudományos hátteréül pedig a gazdasági viselkedéstudományhoz (Samson 2017) vagy a földrajzi viselkedéstudományhoz (Montello 2018) hasonlóan létre kell hozni az oktatási viselkedéstudományt (educational behavior science). Bourdieu (1984) habituselméletéből kiindulva ez komplex rendszerként tekint az oktatási térben történő tanulási és tanítási tevékenységekre, döntésekre és aktivitásokra, amelyeket a rendszerpercepciók és -értelmezések egyénileg integrált és interiorizált, ugyanakkor kulturálisan konstruálódó, társadalmicsoport-hatásoknak kitett különféle változatai mozgatnak az oktatási életút teljes hosszában (LLL), szélességében (LWL) és mélységében (LDL) (Bélanger 2016).

\section{IRODALOM}

Bankó, M. (2009) Szakmai fejlődésképletek angoltanárként végzettek körében. A Pannon Egyetem nappali tagozaton egyetemi képzésben 2001 júniusában angoltanárként végzettek szakmai életútjának néhány jellemzője. Doktori értekezés. Kézirat.

Barbalet, J. M. (1986) Limitations of Class Theory and the Dissappearance of Status. The Problem of the New Middle Class. Sociology, Vol. 20. No. 4. pp. 557-575.

Bélanger, P. (2016) Self-construction and Social Transformation. Lifelong, Lifewide and Lifedeep Learning. Montreal, Les Presses de l'Université de Montreal.

Bíró Zs. H. (2020) Az árnyékoktatásról internetes magánoktatói hirdetések tükrében. Educatio, Vol. 29. No. 2. pp. 243-260.

Borbély-Pecze T. B., Kovács T. \& Répáczki R. (2012) Az életpálya-tanácsadási (Lifelong Guidance) szakpolitikai és szolgáltatásmodell az új évezredben. http://www. munkaugyiszemle.hu/sites/default/files/borbely_et_0.pdf [Letöltve: 2020. 05. 17.]

Bourdieu, P. (1984) Distinction. A Social Critique of the Judgment of Taste. Cambridge, Harvard University Press.

Bourdieu, P. (2003) Vagyoni struktúrák és reprodukciós stratégiák. In: Meleg Cs. (ed.) Iskola és társadalom. Budapest, Dialóg Campus Kiadó. pp. 73-88.

Bray, M. (1999) The Shadow Education System. Private Tutoring and Its Implications for Planners. Paris, UNESCO International Institute for Educational Planning.

Bray, M. (2017) Schooling and Its Supplements. Changing Global Patterns and Implications for Comparative Education. Comparative Education Review, Vol. 61. No. 3. pp. 469-491.

Bray, M. \& Kwo, O. (2014) Regulating Private Tutoring for Public Good. Policy Options for Supplementary Education in Asia. Hong Kong, Comparative Education Research Centre.

Bray, M., Kwo, O. \& Jokić, B. (2015) Introduction. In: M. Bray, O. Kwo \& B. Jokić (eds) Researching Private Supplementary Tutoring. Methodological Lessons from Diverse Cultures. Springer. pp. 3-19.

Ceglédi T. \& Szabó A. É. (2014) Középiskolások és hallgatók az árnyékoktatásban. In: Cegrédi T., Gál. A. \& Nagr Z. (eds) Határtalan oktatáskutatás. Tanulmányok a 75 éves Kozma Tamás részére. Debrecen, Center for Higher Education Research \& Development.

Dawson, W. (2010) Private Tutoring and Mass Schooling in East Asia. Reflections of Inequality in Japan, South Korea, and Cambodia. Asia Pacific Education Review, Vol. 11. No. 1. pp. 14-24. 
Dierkes, J. (2010) Teaching in the Shadow. Operators of Small Shadow Education Institutions in Japan. Asia Pacific Education Review, Vol. 11. No. 1. pp. 25-35.

DŁugosz, P. (2017) Korepetycje uczniów jako przykład praktyki w polu edukacyjnym w Polsce, na Ukrainie i na Węgrzech. Kwartalnik Pedagogiczny, Vol. 244. No. 2. pp. $108-133$.

Doherty, C. \& Dooley, K. (2018) Responsibilising Parents. The Nudge Towards Shadow Tutoring. British Journal of Sociology of Education, Vol. 39. No. 4. pp. 551-566.

Entrich, S. R. (2018) Shadow Education and Social Inequalities in Japan. Evolving Patterns and Conceptual Implications. Springer.

George, C. (1992) Time to Come out of the Shadows. Straits Times, No. 4. (April) p. 28.

Grosh, P. \& Bray, M. (2020) Schools Systems as Breeding Grounds for Shadow Education. Factors Contributing to Private Supplementary Tutoring in West Bengal, India. European Journal of Education. https://onlinelibrary.wiley.com/doi/abs/10.1111/ ejed.12412 [Letöltve: 2020. 05.21.]

Gordon GYőr J. (1998) Mitől hatékony még a japán oktatás. A hivatalos oktatási rendszer tanítási óráin kívüli képzés és oktatás Japánban. Magyar Pedagógia, Vol. 98. No. 4. pp. 273-317.

Gordon GYőr J. (2008) Tömegoktatás és kiegészítő magánoktatás-ipar. Educatio, Vol. 17. No. 2. pp. 253-274.

Gordon Győri J. (2020) Shadow Education. Opportunity for Development. European Journal of Education, Vol. 55. No. 3. pp. 305-310.

FüLÖp M. \& Gordon Győri J. (2020) Magyar középiskolások és egyetemisták nézetei az árnyékoktatás és a verseny kapcsolatáról. Megjelenés alatt.

Ho Nga Hon, H. K. (2010) Hong Kong's Shadow Education. Private Tutoring in Hong Kong. The Hong Kong Anthropologist, Vol. 4. No. 10. pp. 62-85.

Hussein, M. G. A. (1987) Private Tutoring. A Hidden Educational Problem. Educational Studies in Mathematics, Vol. 18. No. 1. pp. 91-96.

Imre A. (2020) Tanulás félárnyékban - tanórai, tanórán és iskolán kívüli tanulás az általános iskolában. Educatio, Vol. 29. No. 2. pp. 222-242.

Inkei P., Koncz G. \& Pőcze G. (1988) The Diversification of the Educational Field in Hungary. Paris, Unesco International Institute for Educational Planning.

Józsa K. \& Nikolov M. (2005) Az angol és német nyelvi készségek fejlettségét befolyásoló tényezök. Magyar Pedagógia, Vol. 105. No. 3. pp. 307-337.

Kalmár É. (1995) A kínai vizsgarendszer. Educatio, Vol. 4. No. 3. pp. 501-511.

Kassotakis, M. \& Verdis, A. (2018) Shadow Education in Greece. Characteristics, Consequences and Eradication Efforts. In: M. Bray, A. E. Mazawi \& R. G. Sultana (eds) Power Dynamics and Implications for Learning and Equity. Rotterdam, Sense Pulbishers. pp. 93-113.

Kim, Y. Ch. \& Jung, J. (2019a) Shadow Education as Worldwide Curriculum Studies. Palgrave Macmillan.

Kim, Y. Ch. \& Jung, J. (2019b) Conceptualizing Shadow Curriculum. Definition, Features and the Changing Landscapes of Learning Cultures. Journal of Curriculum Studies, Vol. 51. No. 2. pp. 141-161.

Kobakidze, M. N. (2018) Teachers as Tutors. Market Dynamics in Georgia. Springer.

Kobakidze, M. N. \& Suter, L. (2020) The Global Diversity of Shadow Education. European Journal of Education. https://onlinelibrary.wiley.com/doi/abs/10.1111/ejed.12411 [Letöltve: 2020. 05.21.] 
Kobayashi, Y. (2018) The Effect of Shadow Education Vouchers after the Great East Japan Earthquake. Evidence from Regression Discontinuity Design. Tokyo, Reiti.

Kosunen, S. (2018) Access to Higher Education in Finland. Emerging Processes of Hidden Privatization. Nordic Journal of Studies in Educational Policy, Vol. 4. No. 2. pp. 67-77.

LeE, S. (2006) Prestige-oriented View of College Entrance and Shadow Education in South Korea. Factors Influencing Parental Expenditures on Private Tutoring. Doctoral thesis. Kézirat.

Manzon, M. \& Areepattamannil, S. (2014) Shadow Educations. Mapping the Global Discourse. Asia Pacific Journal of Education, Vol. 34. No. 4. pp. 389-402.

Marimuthu, T., Singh, J. S., Ahmad, K., Lim, H. K., Mukherjee, H., Osman, S., Chelliah, T., Sharma, J. R., Salleh, N. M., Yong, L., Lim, T. L., Sukumaran, S., Thong, L. K. \& Jamaluddin, W. (1991) Extra-school Instruction, Social Equity and Educational Quality [in Malaysia]. Singapore, International Development Research Centre.

Mayer J. (2003) A tanulók munkaterheiről. Új Pedagógiai Szemle, Vol. 53. No. 7-8. pp. 70-87.

Montello, D. R. (2018) Handbook of Behavioral and Cognitive Geography. Edward Elgar Publishing.

Murnane, R. J., Waldman, M. R., Willett, J. B., Bos, M. S. \& Vegas, E. (2017) The Consequences of Educational Voucher Reform in Chile. Inter-American Development Bank Education Division.

PÁsku J. \& MüNnıCh, Á. (2000) Az extrakurrikuláris oktatás nem specifikus hatásai. Magyar Pedagógia, Vol. 100. No. 1. pp. 59-77.

Polóny I. (2020). Az árnyékoktatás oktatásgazdasági közelítésben. Educatio, Vol. 29. No. 2. pp. 188-204.

Qin, L., QIN, Y., CHI, M. \& MA, J. (2019) 影子教育研究的发展脉络探析 [Az árnyékoktatás kutatásának története.] 教育学术月刊, No. 5. pp. 70-77, 95.

Rohlen, Thomas P. (1980) The Juku Phenomenon. An Exploratory Essay. Journal of Japanese Studies, Vol. 6. No. 2. pp. 207-242.

SAmson, A. (2017, ed.) The Behavioral Economics Guide 2017 (with an Introduction by Cass Sunstein). http://www.behavioraleconomics.com [Letöltve: 2020. 05. 17.]

SETÉNyi J. (2020) Az „árnyékoktatás” metaforájától a tanulási rendszerekig. Educatio, Vol. 29. No. 2. pp. 261-278.

Silber, K. H. (1972) The Learning System. A New Approach to Facilitating Learning Based on Freedom. The Future and Educational Technology. http://www.iirp.edu/images/ pdf/92906_THE_LEARNING_SYSTEM7.pdf [Letöltve: 2020. 05. 17.]

Stevenson, D. \& Baker, D. (1992) Shadow Education and Allocation in Formal Schooling. Transition to University in Japan. American Journal of Sociology. Vol 97. No. 6. pp. 1639-1657.

Suter, L. E. (2016) Outside School Time. An Examination of Science Achievement and Non-cognitive Characteristics of 15-year Olds in Several Countries. International Journal of Science Education, Vol. 38. No. 4. pp. 663-687.

Szemerszki M. (2020) Különórák az iskolában és az iskolán kívül. Educatio, Vol. 29. No. 2. pp. 205-221.

Szénay M. (2003) A diákok „munkaideje”. In: Mayer J. (ed.) A tanulók munkaterhei Magyarországon. Budapest, Országos Közoktatási Intézet. http://ofi.hu/tudastar/tanulokmunkaterhei/diakok-munkaideje [Letöltve: 2020. 05. 17.] 
Tooley, J. (1999) The Global Education Industry. Lessons from Private Education in Developing Countries. London, The Institute of Economic Affairs.

Tsiplakides, I. (2018) Shadow Education and Social Class Inequalities in Secondary Education in Greece. The Case of Teaching English as a Foreign Language. International Journal of Sociology of Education, Vol. 7. No. 1. pp. 71-93.

Ural, A. (2012) The Dershane Business in Turkey. Neoliberal Transformation of Education in Turkey. In: K. İnal \& G. Akkaymak (eds) Neoliberal Transformation of Education in Turkey. Political and Ideological Analysis of Educational Reforms in the Age of the AKP. Springer. pp. 151-163.

Zhang, W. (2019) Regulating Private Tutoring in China. Uniform Policies, Diverse Responses. ECNU Review of Education, Vol. 2. No. 1. pp. 25-43.

Zhang, W. \& Bray, M. (2020) Comparative Research on Shadow Education. Achievements, Challenges and the Agenda Ahead. European Journal of Education. Vol. 55. No. 3. pp. 322-341.

Yung, K. W. H. \& Bray, M. (2017) Shadow Education. Features, Expansion and Implications. In: T. K. C. Tse \& M. Lee (eds) Making Sense of Education in Post-handover Hong Kong. Achievements and Challenges. London, Routledge. pp. 95-111.

A cikk a Creative Commons Attribution 4.0 International License (https://creativecommons.org/licenses/ by/4.0/) feltételei szerint publikált Open Access közlemény, melynek szellemében a cikk bármilyen médiumban szabadon felhasználható, megosztható és újraközölhető, feltéve, hogy az eredeti szerző és a közlés helye, illetve a CC License linkje és az esetlegesen végrehajtott módosítások feltüntetésre kerülnek. (SID_1) 